DOI

\title{
ВИКЛАДАННЯ КУРСУ ДЕРМАТОЛОГІЇ ТА ВЕНЕРОЛОГІЇ СТУДЕНТАМ-МЕДИКАМ
}

В. В. Шухтін, В. I. Хрущ

\author{
Одеський національний медичний університет
}

\section{TEACHING OF THE DERMATOLOGY AND VENEROLOGY COURSE FOR MEDICAL STUDENTS}

\author{
V. V. Shukhtin, V. I. Khrushch \\ Odesa National Medical University
}

\begin{abstract}
Забезпечення високого рівня підготовки лікарів є вимогою сьогодення, оскільки цей фах вимагає належних знань і вмінь для надання належної медичної допомоги населенню. У статті представлені сучасні тенденції розвитку дерматології та венерології, підходи до вдосконалення її викладання в медичних університетах. Організація навчально-методичної роботи орієнтована на кінцеву мету навчання й професійну лікарську діяльність.
\end{abstract}

Ensuring a high level of training of doctors are demanding today, because this profession requires adequate knowledge and skills to provide proper medical care. The paper presents the current trends of Dermatology and Venereology, approaches to the improvement of teaching in medical universities. Organization of educational work is focused on the ultimate goal of medical education and professional activities.

Вступ. Шкірні та венеричні хвороби широко поширені і часто зустрічаються в практиці лікаря. Вони мають значну питому вагу в загальній структурі хвороб людини, тому процес викладання шкірних і венеричних хвороб вимагає високого рівня теоретичної та практичної підготовленості викладача. Зміст предмета має бути науковим, що визначає специфіку методики викладання курсу шкірних та венеричних хвороб. Мета дерматовенерології як предмета - повідомляти студентам-медикам відомості про етіологію, патогенез, клінічну картину, методи діагностики та способи лікування шкірних і венеричних хвороб. Зміст курсу дерматовенерології визначає своєрідність всієї системи викладання цього предмета. На додаток до основної форми викладання (теоретичні заняття) необхідні й інші форми навчальної роботи - практичні заняття, курсові та дипломні роботи.

Основна частина. Студенти, що займаються на кафедрі дерматовенерології, можуть бути залучені для проведення санітарно-просвітницької діяльності з профілактики інфекцій, які передаються статевим шляхом, що дозволить їм детально опрацювати актуальні на сьогодні питання профілактики ІПСШ.

\footnotetext{
(C) В. В. Шухтін, В. I. Хрущ
}

У методично правильно організованому процесі викладання всі форми навчання допомагають розвивати медичні поняття про шкірні і венеричні хвороби, клінічне мислення лікаря, що необхідно для професійного виконання обов' язків лікаря-клініциста, та практичні навички лікарядерматовенеролога, сприяють формуванню готовності до практичної діяльності лікаря з використанням наукових даних, а також ведуть до формування особистості.

Особливу увагу необхідно приділяти науковій діяльності, залучати студентів до проведених на кафедрі наукових експериментів. Ця частина навчального процесу сприятиме інтегруванню отриманих даних у ході експериментальної діяльності, теоретичних знань і практичних навичок, а також розвиватиме аналітичні здібності.

Важливою є участь студентів у розробці творчих проектів, при яких ними створюється продукт, що володіє суб' єктивною і об'єктивною новизною. Навчальний процес повинен включати методику обстеження хворих та складання історії хвороби, тестові завдання. Окремо необхідно приділяти час практичним навичкам, які необхідні для роботи в клініці шкірних і венеричних хвороб, для формування у студентів діагностичних навичок, що до- 
зволяють при роботі в будь-якій області медицини запідозрити у пацієнта захворювання дерматовенерологічного характеру і оцінити його прогноз.

Виклад матеріалу викладачем не повинен виступати як парадигма, необхідно вирішувати науковопрактичні питання колегіально, за допомогою відкритих дискусій. Все це спрямовано на формування у студентів творчого ставлення до досліджуваного матеріалу - вміння розгледіти в ньому проблеми і знайти можливий шлях їх розв'язання. Студентам необхідно самостійно працювати над засвоєнням нового для них матеріалу з курсу шкірних та венеричних хвороб.

Дерматовенерологія тісно перекликається з іншими областями медичної науки, тому у викладанні курсу шкірних та венеричних хвороб не повинно бути односпрямованого викладу навчального матеріалу, необхідно враховувати не тільки вплив хвороб шкіри на інші органи і системи, а й вплив патології внутрішніх органів на стан шкірних покривів.

Освіта дозволяє орієнтуватися у світі альтернативних цінностей, здійснювати їх вибір і оцінювати результати цього вибору як з точки зору прийнятих і сповідуваних цінностей, так і з точки зору досягнення успіху в пізнавальній, перетворювальній, ціннісно-орієнтаційній та іншій діяльності щодо вирішення соціально значущих проблем.

Спираючись на сучасні педагогічні технології, враховуючи інтереси студентів, через активні методи та форми навчання викладачі долучають студентів до майбутньої професії, до світу науки. Самостійна робота з досліджуваних предметів розвиває індивідуальні здібності студента, веде до поповнення і вдосконалення його знань і практичних

\section{Список літератури}

1. Дерматовенерология : учебник / В. В. Чеботарев, О. Б. Тамразова, Н. В. Чеботарева, А. В. Одинец. - М. : ГЭОТАР-Медиа, 2013. - С. 15-21.

2. Коваленко О. Є. Проблеми методичної підготовки викладачів спеціальних дисциплін / О. Є. Коваленко // Педагогіка і психологія. - 1996. - № 4. навичок, закріплення отриманої раніше інформації. Написання і захист реферативних, курсових i дипломних робіт розширює знання студентів 3 даних питань і $€$ важливою складовою частиною навчального процесу. Розвиток навичок самоосвіти досягається використанням інноваційних форм навчання: навчальних тестів, мультимедійних посібників для самостійної роботи.

3 метою розвитку пізнавального інтересу до досліджуваних предметів, розширення і поглиблення знань, активізації творчого потенціалу студентів на кафедрах проводяться олімпіади з предметів. Педагогічна діяльність, спрямована на навчання, розвиток і виховання студентів, забезпечує ефективність процесу формування ціннісного ставлення майбутніх фахівців до професійної діяльності.

Висновки: 1. Процес викладання предмета “Шкірні і венеричні хвороби” в медичному ВНЗ вимагає високого рівня теоретичної та практичної підготовленості викладача у сфері національного й міжнародного досвіду діагностики та лікування хвороб даної категорії.

2. У методично правильно організованому процесі викладання всі форми навчання допомагають розвивати медичні поняття про шкірні і венеричні хвороби, клінічне мислення лікаря, що необхідно для професійного виконання обов'язків лікаряклініциста, а також практичні навички лікарядерматовенеролога, що сприяє формуванню готовності до практичної діяльності лікаря з використанням наукових даних.

3. Педагогічна діяльність, спрямована на навчання, розвиток і виховання студентів, забезпечує ефективність процесу формування ціннісного ставлення майбутніх фахівців до професійної діяльності.

3. Волосовець О. П. Питання якості освіти у контексті впровадження засад Болонської декларації у вищій медичній школі / О. П. Волосовець // Медична освіта. - 2005. - № 2. - С. 12-16.

4. Суліма $€$. Невідкладні завдання системи вищої освіти на новому етапі Болонського процесу / Є. Суліма // Вища школа. - 2010. - № 1. - С. 5-13. 